\title{
Connected Variations of Meteorological and Electrical Quantities of Surface Atmosphere under the Influence of Heavy Rain
}

\author{
Vladimir Kalchikhin ${ }^{1, *}$, Alexey Kobzev ${ }^{1}$, Petr Nagorskiy ${ }^{1,2}$, Mariya Oglezneva ${ }^{1,2}$, \\ Konstantin Pustovalov ${ }^{1,2}{ }^{\mathbb{D}}$, Sergei Smirnov ${ }^{1} \mathbb{D}$ and Dmitriy Filatov ${ }^{1}$ \\ 1 Institute of Monitoring of Climatic and Ecological Systems of the Siberian Branch of the Russian Academy of \\ Sciences, 10/3, Academicheskii Ave., 634055 Tomsk, Russia; alexey-kobzev@mail.ru (A.K.); \\ npm_sta@mail.ru (P.N.); oglezneva.m@yandex.ru (M.O.); const.pv@yandex.ru (K.P.); \\ smirnov@imces.ru (S.S.); dmitrii.04101995@gmail.com (D.F.) \\ 2 Department of Meteorology and Climatology, National Research Tomsk State University, 36, Lenin Ave., \\ 634050 Tomsk, Russia \\ * Correspondence: vvk@imces.ru; Tel.: +7-3822-492024 (ext. 1056)
}

Received: 15 October 2020; Accepted: 29 October 2020; Published: 4 November 2020

check for updates

\begin{abstract}
The electrical state of the surface atmosphere changes significantly under the influence of cloudiness and atmospheric phenomena, including atmospheric precipitation. These features can be used for possible diagnostics of precipitation and improvement of their characteristics based on variations of atmospheric-electrical quantities in the surface layer. Studies of variations of meteorological and atmospheric-electrical quantities in the surface layer were carried out during the heavy rainfall associated with the cumulonimbus $(\mathrm{Cb})$ clouds passage. Meteorological and atmospheric-electrical observations in the Geophysical Observatory of the Institute of Monitoring of Climatic and Ecological Systems are presented in this paper. Precipitation data are used to identify periods of heavy rainfall $\geq 5 \mathrm{~mm} / \mathrm{h}$. Information of weather stations and satellites is used to separate the heavy rainfall events by synoptic conditions like thunderstorms and showers of frontal or internal air masses. We find that rains associated with the frontal $\mathrm{Cb}$ clouds produce more abrupt changes in negative electrical conductivity in comparison with the $\mathrm{Cb}$ clouds in internal air masses. The significant increase in negative electrical conductivity (more than two times vs. normal values) occurs typically during the passage of frontal $\mathrm{Cb}$ and heavy rain with droplet size greater than $4 \mathrm{~mm}$.
\end{abstract}

Keywords: atmospheric electricity; atmospheric electric field; air electric conductivity; electrode layer; weather fronts; cumulonimbus clouds; thunderstorm; heavy rain; shower

\section{Introduction}

The hazardous weather phenomena pose a threat to human beings and their economic activity, and they also have a major environmental impact. Intense and prolonged precipitation is one of the severe events, which is becoming an increasingly detrimental factor for natural systems and society. The spatial and temporal distribution of precipitation may have substantial variability, even within relatively homogeneous physical and geographical areas.

Currently, monitoring of storm rainfall on the meso- $\beta$ scale in Western Siberia is carried out primarily by observations at the Roshydromet weather stations network. Such collected data cannot provide detailed spatial and temporal distribution as well as identify the most likely areas for severe storm rainfall or evaluate the relationship with changes in atmospheric electrical parameters and meteorological values, particularly in small-scale convective processes. 
Electrical quantities in the surface atmosphere are very sensitive to meteorological conditions [1-7]. Taking this feature into account, it seems possible to diagnose changes in precipitation and specify its characteristics based on variations of electrical quantities in the surface layer (potential gradient of the electric field $\nabla \varphi=-E$ and polar electric conductivity $\lambda_{ \pm}$).

The electrical structure of the surface atmosphere under fair-weather conditions has been investigated in sufficient detail [8-18]; while the processes at disturbed weather (clouds, precipitation, blizzards, fogs, thunderstorms, etc.) are less studied. Based on previous research of fluctuations in electrical quantities during disturbed weather conditions, the variability and representative values of $\nabla \varphi$ have been identified [3-7,9-33]. The passage of rain-bearing cumulonimbus $(\mathrm{Cb})$ clouds has been shown to cause both higher-frequency $\nabla \varphi$ variation and smoother changes in $\nabla \varphi$, associated with the space charges in such clouds. The work presents the analysis of $\nabla \varphi$ values for the summer period of 2018-2019 during the $\mathrm{Cb}$ passage of different genesis and examines the impact of storm rain on the electric state of the surface atmosphere.

It is known that the air electrical conductivity in the surface layer is more than $90 \%$ determined by the concentration of small ions. In turn, the variability of small ion concentration, and hence the air electrical conductivity, depends on meteorological phenomena and air pollution [34-36].

The processes of ion production during rainfall cause an increase in the concentration of small ions in the surface layer. In addition, at that time the concentration of negative ions always prevails over the concentration of positive ions [37-40]. However, at present, the mechanisms of increasing ions during rain and near waterfalls have not yet been fully understood.

\section{Experiments}

The study area is located in the south-east of Western Siberia. Geophysical, meteorological and environmental studies, testing and comparison of new equipment and technologies are carried out at the Geophysical Observatory of the Institute of Monitoring of Climatic and Ecological Systems (GO IMCES) based in Tomsk and its suburbs (Figure 1a). The coordinates of the base station of GO IMCES are $56^{\circ} 28^{\prime} 32^{\prime \prime}\left(56.48^{\circ}\right) \mathrm{N}, 85^{\circ} 03^{\prime} 17^{\prime \prime}\left(85.05^{\circ}\right) \mathrm{E}$, and its altitude is $167 \mathrm{~m}$ above see level). Description of GO IMCES are available on its website [41] (in Russian). Figure 1b displays the overall equipment layout plan at the GO IMCES as a base station. Furthermore, remote stations placed at a distance of 6 to $60 \mathrm{~km}$ from the base operate in monitoring mode. Since 2006, high temporal resolution observations of atmospheric-electrical, actinometric and meteorological values including turbulence have been conducted.

Meteorological values were registered by the automatic weather stations AMK-03 (IMCES, Russia) [42] and weather transmitter WXT520 (Vaisala, Finland) with a time resolution of 1 min. The precipitation characteristics were measured with the WXT520 and the optical rain gauge OPTIOS. The WXT520 is equipped with a Vaisala RAINCAP sensor, which detects the impact of individual rain drops or hail stones. The sensor has a collecting area of $60 \mathrm{~cm}^{2}$. Incoming signals are proportional to the volume of droplets/hail stones. The RAINCAP sensor is able to measure the total precipitation amount with output resolution $0.01 \mathrm{~mm}$ and field accuracy for daily accumulation $5 \%$; rain intensity (running one minute on average in 10-s steps and measuring range $0-2000 \mathrm{~mm} / \mathrm{h}$ ); rain duration with output resolution $10 \mathrm{~s}$. The optical rain gauge OPTIOS, was designed in the IMCES [43,44] as a precipitation measurement unit for the automatic weather station AMK-03, and its modifications [42]. The functional scheme of this device is shown in Figure 2.

The device is based on the principle of obtaining and analyzing shaded drop images. For its implementation, the scheme is applied, where a collimated light beam from a source enters to a linear sensor, forming a horizontal measuring sampling plane (Figure 2). Linear sensor scan frequency $(\sim 20 \mathrm{kHz})$ defines the scale of the cross-sections for each precipitation particle moving through a measuring plane. On the basis of the measurement data analysis, the microstructural (diameter $(D)$ and raindrop fall velocity $(v)$ ) and integral precipitation characteristics (precipitation intensity $\left(I_{\mathrm{p}}\right)$ and total precipitation amount) are determined. The size of the measuring area is $48 \mathrm{~cm}^{2}$. 


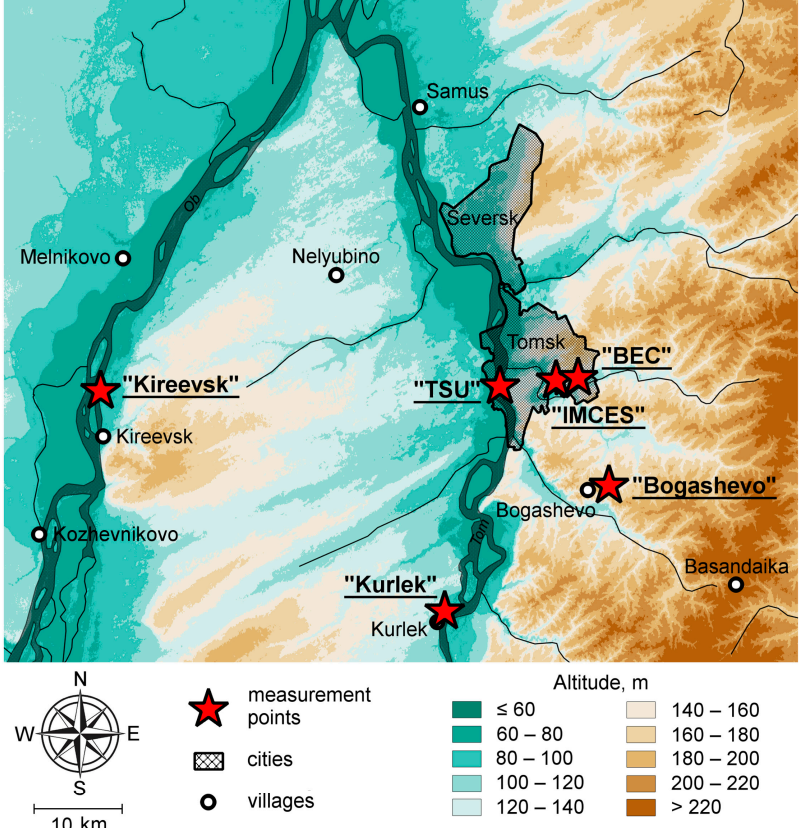

(a)

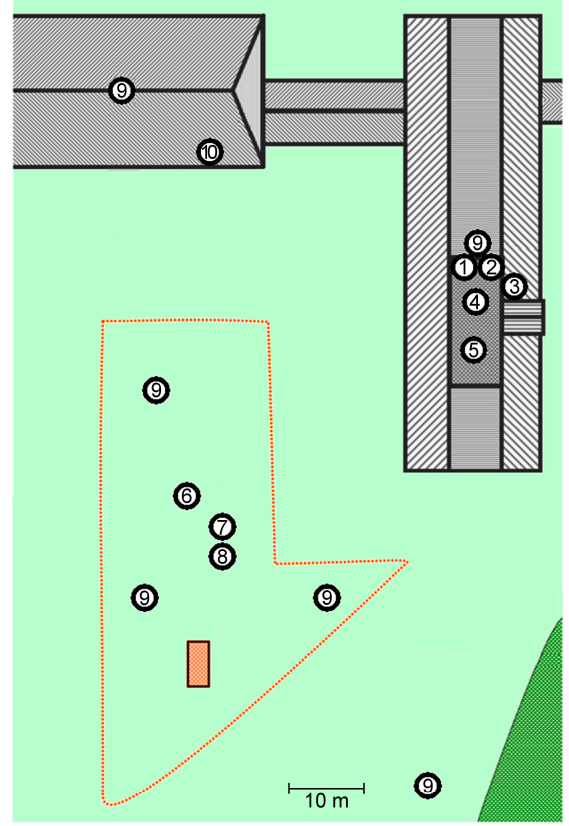

(b)

Figure 1. Location of the GO IMCES and remote stations (a). Layout equipment plan at base station, the GO IMCES (b) 1 is the weather transmitter WXT520; 2 is the anemorumbometer M-63; 3 is the polar electrical conductivity meter "Electroconductivity-2"; 4 depicts sensors of temperature, humidity and pressure; 5 depicts the pyranometer CM11, and the radiometers NILU-UV-6T and M-124; 6 depicts the electric field mill meters "Field-2" and CS110; 7 is the optical rain gauge OPTIOS; 8 is the Tretyakov rain gauge; 9 depicts the automatic weather stations AMK-03; 10 are the integrating nephelometer, the aerodynamic particle sizer and the scanning mobility particle sizer.

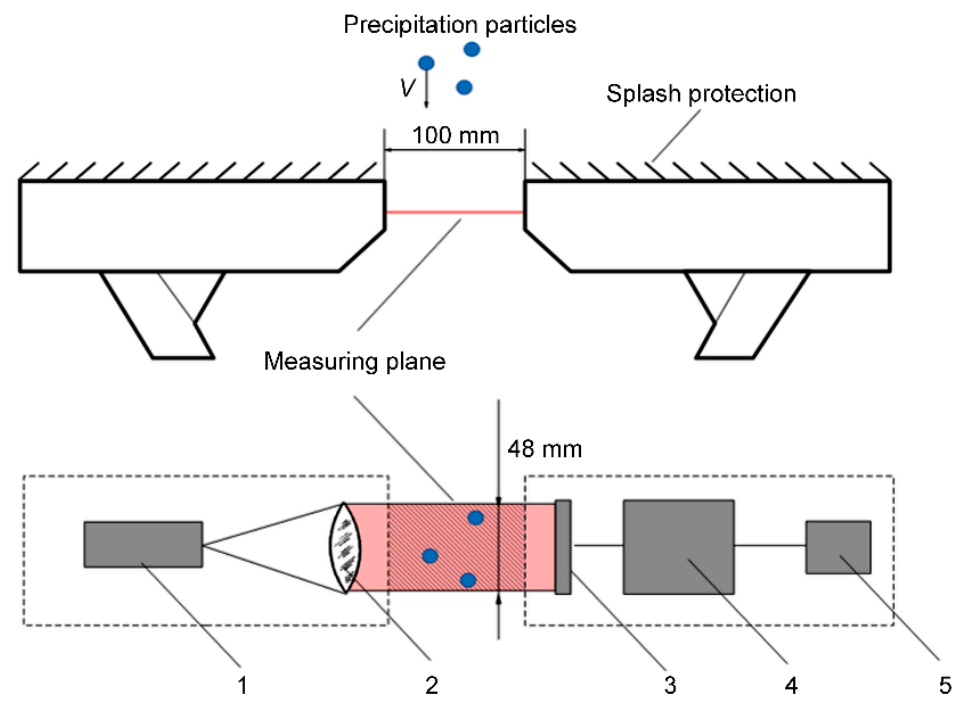

Figure 2. Functional scheme of the optical rain gauge OPTIOS: 1 is an optical radiation source; 2 is an optical lens system; 3 is linear optical sensor; 4 is forming unit of measured data; 5 is output interface.

Measurements of atmospheric electrical values were conducted using the electric field mill meters "Field-2" and CS110 with a time averaging of 30 and $1 \mathrm{~s}$, respectively, the polar electric conductivity is measured by the "Electroconductivity-2" with a time averaging of $30 \mathrm{~s}$.

"Electroconductivity-2" is a double aspiration measuring capacitor. The device implements a method based on measuring the current of ions deposited from the air flow onto one of the capacitor plates, 
between which an electric field is created. The instrument measures the polar (positive and negative) electrical conductivity of air in the range of $\pm 25 \times 10^{-15} \mathrm{~s} / \mathrm{m}$ with an accuracy of $\pm 10 \%$. The air ion critical mobility for "Electroconductivity-2" is $\geq 0.4 \mathrm{~cm}^{2} /(\mathrm{V} \times \mathrm{s})$. "Electroconductivity-2" was installed on a horizontal bracket attached to the wall of the building at a height of $25 \mathrm{~m}$ above the ground. "Field-2" is located on height $1 \mathrm{~m}$ on the metal grid $(3 \times 3 \mathrm{~m})$. "Field-2" measures the values of the potential gradient of the electric field in the range of $\pm 5000 \mathrm{~V} / \mathrm{m}$ with an accuracy of $\pm 5 \%$. The metal grid reduces the influence of the surface corona space charge on the electric field potential gradient values measured by "Field-2". "Field-2" and "Electroconductivity-2" were produced and calibrated by the calibrator of electric field strength, KNEP-1M (a range is $0 \pm 5000 \mathrm{~V} / \mathrm{m}$, an accuracy is $1.5 \%$ ), the reference meter of air electrical conductivity, "Electroconductivity-2E" (a range is $\pm(5-40) \times 10^{-15} \mathrm{~s} / \mathrm{m}$, a basic error is $5 \%$ ), respectively, in the Voeikov Main Geophysical Observatory (St. Petersburg, Russia).

The field mill meter CS110 is located on a height of $2 \mathrm{~m}$ on the tripod mast. It measures electric field potential gradient values in the range of $\pm 22,300 \mathrm{~V} / \mathrm{m}$ with an accuracy of $\pm 5 \%+8 \mathrm{~V} / \mathrm{m}$. Until 2017, the measuring data of "Field-2" were used, and in the subsequent period, the data from the field mill meter CS110. The conversion factor was calculated, allowing us to combine the measuring series of these meters. Variations of electric field potential gradient during the selected events were analyzed.

\section{Results}

For study, only cases with rain showers for 2018-2019 were chosen from meteorological observations and the results from the precipitation measurements obtained at the GO IMCES. Data from visual observations of cloudiness and atmospheric phenomena reported in the GO IMCES with an interval of $1 \mathrm{~h}$ in daylight time and the Tomsk weather station (6 km away from the GO IMCES) were used when selecting cases. In addition, the study included synoptic maps with frontal study [45] and the MODIS spectroradiometer data mounted on the Aqua and Terra satellites [46].

In the next step, the selected data omitted all cases where the maximum intensity of precipitation did not exceed $5 \mathrm{~mm} / \mathrm{h}[33,43]$. As a result, 45 cases of heavy rainfall were identified and analyzed. In 22 cases (49\%) there was a significant, short-term increase in negative electrical conductivity; in 15 cases $(33 \%)$ no increase was recorded; in eight cases $(18 \%)$ there were uncertain situations when the negative electrical conductivity variations could not be unequivocally differentiated. The "significant, short-term increase" is identified as the increase in negative air electrical conductivity more than two times $(200 \%$ or more) vs. undisturbed values (see Appendix A Table A1). To estimate the undisturbed values for each case, the $10 \mathrm{~min}$ interval preceding the passage of $\mathrm{Cb}$ and precipitation was used.

The list of analyzed cases is given in Table A1. The same table presents data on the synoptic condition, cloudiness and atmospheric phenomena obtained from the visual observations, the Tomsk weather station, synoptic maps and the MODIS spectroradiometer.

The data analysis provided in Table A1 revealed that the cases with the growth effect $\lambda_{-}$and its absence for the frontal heavy rains are $95 \%$ and $5 \%$, respectively, and for the intra-mass showers they are $13 \%$ and $87 \%$, respectively.

\section{Discussion}

Let us analyze variations of $I_{\mathrm{p}}, \lambda_{ \pm}$and $\nabla \varphi$ for frontal and intra-mass $C b$ illustrated in Figures 3 and 4 , respectively. The chosen cases present a typical example of $C b$ passage with heavy rainfall recorded in 2018-2019. A cold front cloud system ( $C b, A c, C i$ clouds and heavy rain) occurred on 17 June 2019; 23 June 2019 characterized by an intra-mass cloudiness $(C b, S c, A c$, thunderstorm and shower). In the first case, maximum of $I_{\mathrm{p}}$ is roughly equal to $45 \mathrm{~mm} / \mathrm{h}$ and almost doubled compared to the second $(\sim 25 \mathrm{~mm} / \mathrm{h})$. 

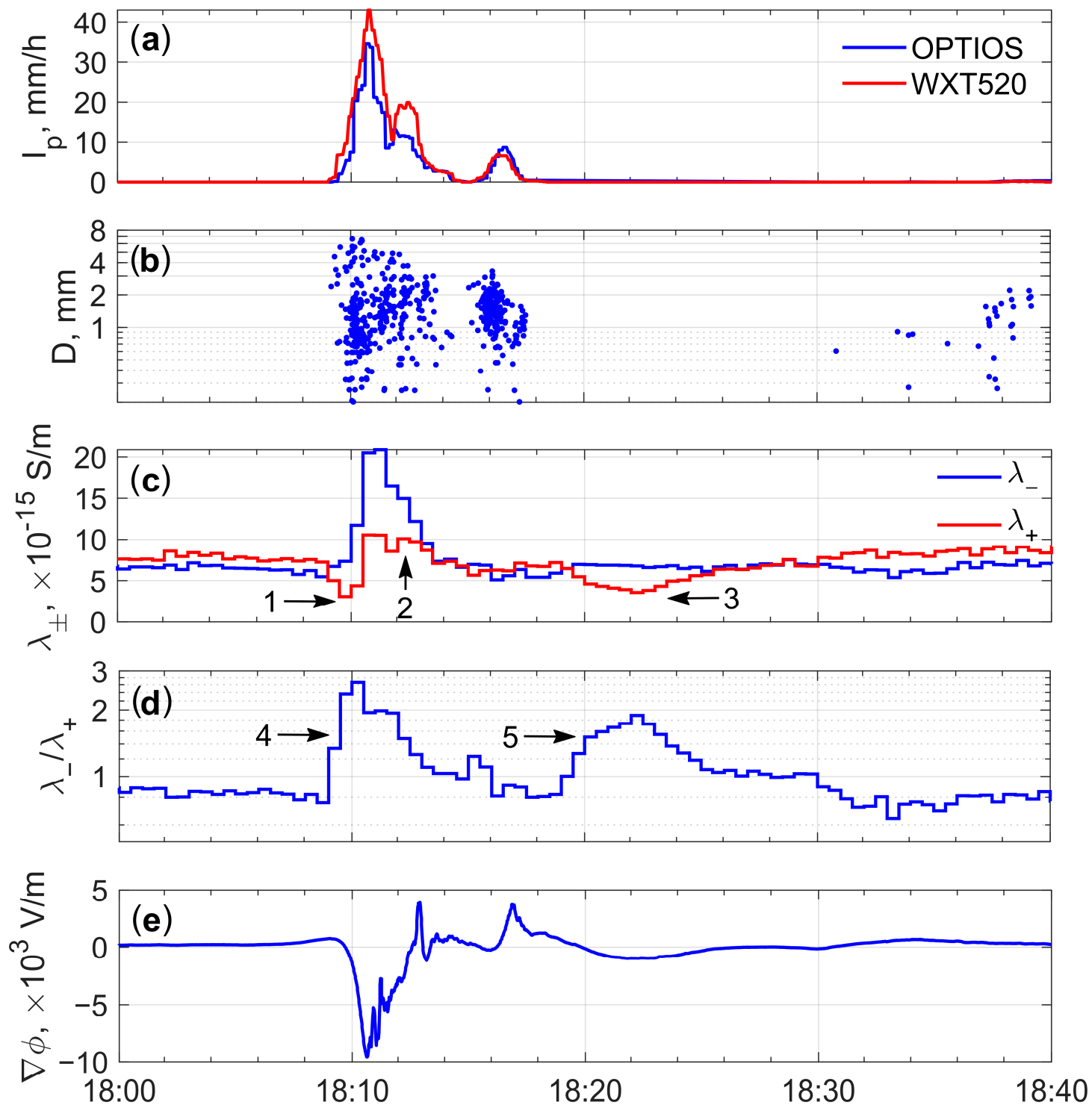

Figure 3. Pattern of atmospheric electric values and frontal precipitation characteristics on 17 June 2019. The plots (from up to down) show the variation of precipitation intensity $I_{\mathrm{p}}(\mathbf{a})$, droplet density written in time-droplet diameter coordinates $D(\mathbf{b})$, electroconductivity $\lambda_{-}, \lambda_{+}(\mathbf{c})$, electroconductivity ratio $\lambda_{-} / \lambda_{+}(\mathbf{d})$ and potential gradient $(\nabla \varphi)$, recalculated based on the conversion factor $(\mathbf{e})$. Here is shown a local time.

The change of electric conductivity ratio of different polarities $\left(\lambda_{-} / \lambda_{+}\right)$under the influence of heavy rainfall is presented in Figure 3d. The first maximum is to be correlated with an increase in light negative-ion amount under the influence of heavy rainfall (see an arrow 4, Figure 3d). As a consequence, a negative volume charge is produced in the surface atmosphere. The second maximum of $\lambda_{-} / \lambda_{+}$, labelled arrow 5 , is triggered after the end of the rainfall by dropping the amount of light positive ions (Figure $3 c$, arrow 3 ).

The passing cold front cloud system is considered below. No significant increase in positive electrical conductivity was registered during heavy rain (Figure 3c). Despite high negative $\nabla \varphi$ values (Figure 3e), no decrease in $\lambda_{+}$was recorded to near zero values (Figure 3c, arrow 1). In Ref. [30], experimental and model studies of this process were considered during the passage of $\mathrm{Cb}$ and in the absence of precipitation. Instead, $\lambda_{+}$increased to values above the undisturbed level (Figure $3 c$, arrow 2). The highlighted effect coincided in time with the maximum intensity of rainfall. 

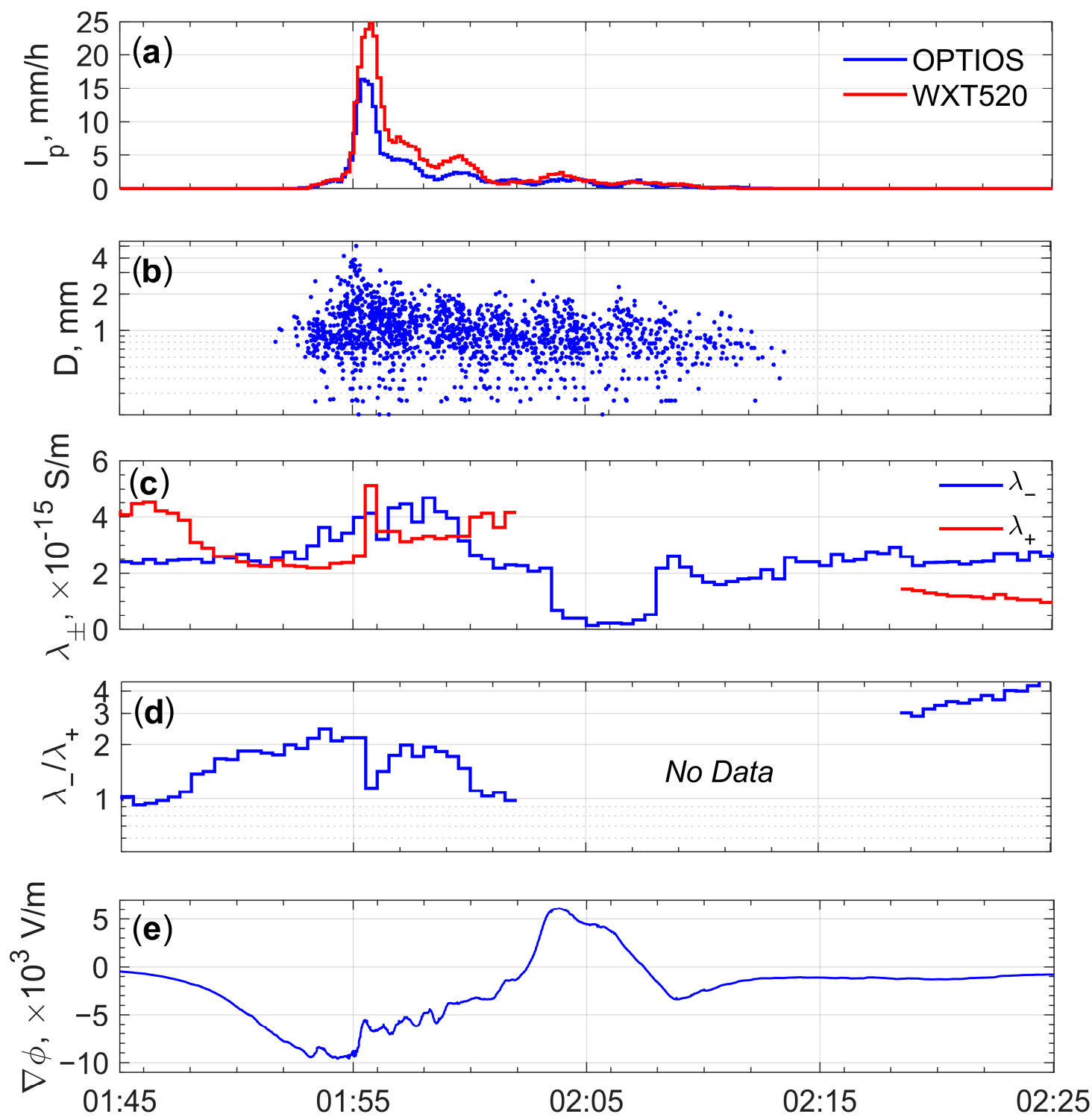

Figure 4. Pattern of atmospheric electric values and intra-mass precipitation characteristics for 23 June 2019. The plots (from up to down) show the variation of precipitation intensity $I_{\mathrm{p}}$ (a), droplet density written in time-droplet diameter coordinates $D(\mathbf{b})$, electroconductivity $\lambda_{-}, \lambda_{+}(\mathbf{c})$, electroconductivity ratio $\lambda_{-} / \lambda_{+}(\mathbf{d})$ and potential gradient $(\nabla \varphi)$, recalculated based on the conversion factor $(\mathbf{e})$. Here is shown a local time.

Next, the data obtained during the passage of $C b$ intra-mass origin are analyzed. For this case, there is no rapid growth in the number $\lambda_{-}$as well as in other related situations. Only a smooth rise $\lambda_{-}$ was registered (Figure 4c) that started before precipitation. At the same time, no reaction $\lambda_{-}(t)$ to a sharp increase in rainfall intensity up to $15-25 \mathrm{~mm} / \mathrm{h}$ was indicated (Figure $4 \mathrm{a}$ ). The drop of negative electrical conductivity almost to zero (Figure 4c) is connected with the $\nabla \varphi$ increase to $+1000 \mathrm{~V}$ and more (Figure $4 \mathrm{~d}$ ) and the formation of volume charge in the electrode layer, consisting mainly of positive light ions. In Ref. [30], more circumstantial consideration is given to the processes of space charge formation in the surface layer under the influence of potential gradient produced by an isolated thunder cell.

The atmospheric electric $\nabla \varphi$ variation (Figure $4 \mathrm{~d}$ ), according to the classification stated in [31], indicates that the precipitating storm cell was characterized first by a negative and then positive $\nabla \varphi$ 
excursions at a late mature stage. Moreover, the first perturbation has been seen to exceed the second both in duration and absolute $\nabla \varphi$ values.

In order to evaluate the distribution of rain droplets by diameter and deposition time $(D, \mathrm{t})$, the sampling plane was divided into cells of size $\Delta D=0.1 \mathrm{~mm}$ and $\Delta \mathrm{t}=5 \mathrm{~s}$. Such segmentation allowed for denoting the temporal variation of the total number of drops and registered drop size distributions (DSDs) for frontal heavy rain and intra-mass showers (Figures $3 b$ and $4 b$ ).

Analysis of the precipitation characteristics, depending on the droplet size and the total volume of all precipitation drops $Q(t)$ showed that the greatest contribution to the current precipitation intensity is produced by droplets greater than $4 \mathrm{~mm}$ (Figure 5a) in the course of frontal heavy rain; the inverse dependency is observed for intra-mass showers (Figure $5 b$ ).

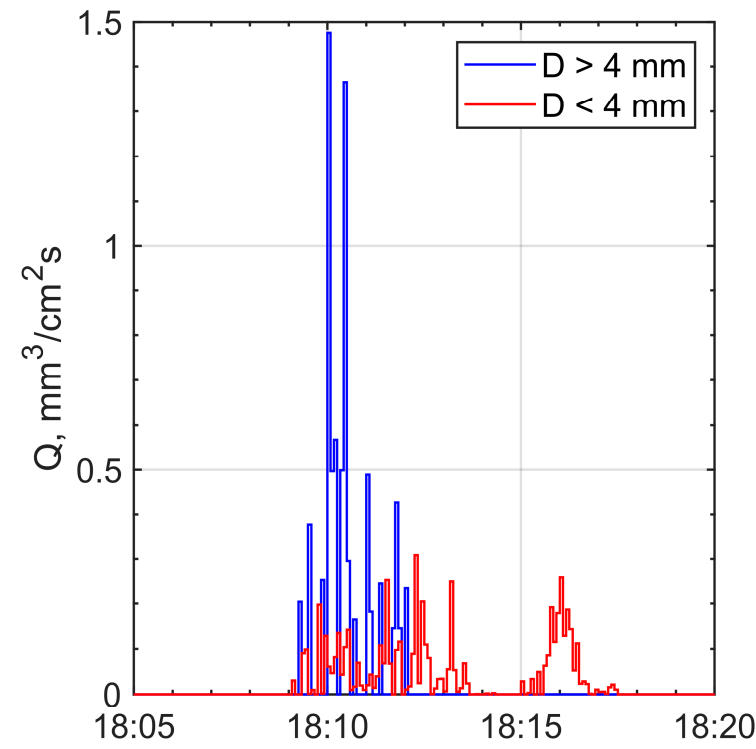

(a)

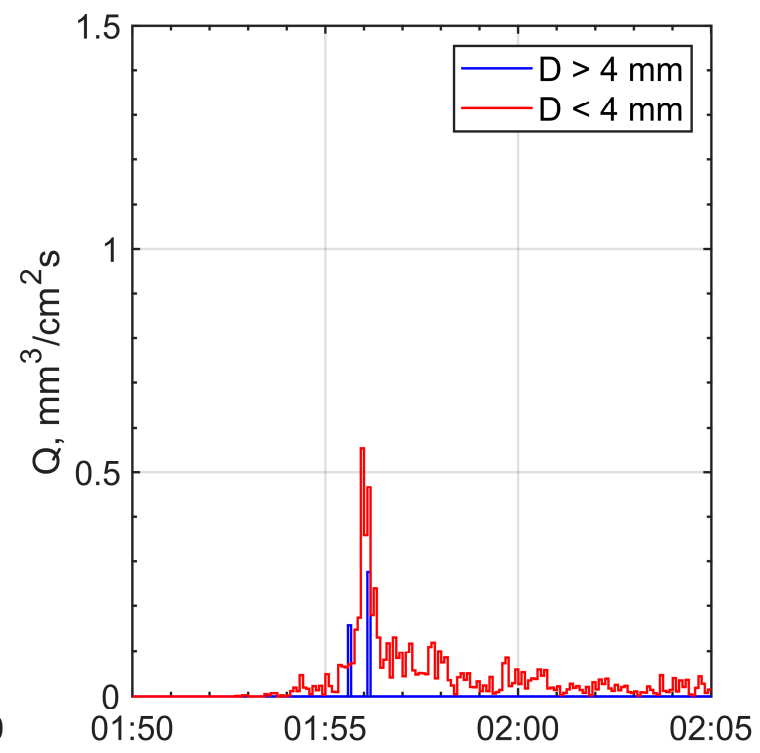

(b)

Figure 5. Rainfall volume regarding frontal heavy rain (a) and intra-mass shower (b). Here $X$ axes represent a local time and $Y$ axes represent an intensity of falling precipitation drops.

The "explosive" increase $\lambda_{-}$(Figure 3c) correlates with rainfall, where droplets have D $>4 \mathrm{~mm}$. Termination of droplets flow leads to relaxation of negative volume charge for a period of $\sim 5 \mathrm{~min}$. The relaxation interval is shown in Figure 3d (marked bracket with number 10).

Hence, the data analysis reveals that variability in electrical conductivity in the surface layer is fundamentally different for frontal heavy rains and intra-mass showers.

The droplet size ranges for the precipitation cases with the growth effect $\lambda_{-}$and its absence being $0.5-7 \mathrm{~mm}$ and $0.5-4 \mathrm{~mm}$, respectively.

The cases with "slow" variations $[4,5,31,45,47]$ of electric field potential gradient during the $\mathrm{Cb}$ passages due to the main charged regions in the clouds are noted. According to [31], these "slow" variations of electric field potential gradient are associated with $\mathrm{Cb}$ clouds in the maturity stage. In addition, the short-period variability of potential gradient [6] caused by the raindrop charges was superimposed on the "slow" variations. These "speed" variations of potential gradient for the frontal $\mathrm{Cb}$ cases coincide with the significant increase in negative conductivity.

\section{Conclusions}

This study of atmospheric-electrical variations in the surface atmosphere associated with the $C b$ passage demonstrates crucial differences in electric quantities during frontal heavy rain and intra-mass showers for the territory of the southeast of Western Siberia. 
The sharp rises in negative electrical conductivity and the formation of negative volumetric charge in the atmospheric surface layer have been typically observed for frontal $C b$ and heavy rain with droplet sizes greater than $4 \mathrm{~mm}$.

The given results may have important significance because depicting the structure of cloud systems and precipitation with much more detail, as well as studying the role of surface atmosphere within the global electrical circuit (GEC) in disturbed weather regions, is useful for developing methods and tools for operational forecasting and diagnosis of hazardous weather phenomena related to thunderstorms and heavy rain or showers.

Author Contributions: Conceptualization, P.N., K.P., A.K.; methodology, V.K., A.K., P.N., K.P., S.S.; software, V.K., K.P., D.F.; validation, V.K., M.O., K.P., S.S.; formal A.K., M.O., K.P. and S.S.; investigation, V.K., A.K., P.N., M.O., K.P., S.S., D.F.; resources, P.N., K.P., A.K.; data curation, S.S., P.N., K.P., V.K., A.K.; writing-original draft preparation, P.N., K.P., V.K., A.K.; writing-review and editing, P.N., K.P., M.O.; visualization, P.N., K.P., V.K., A.K., M.O.; supervision P.N., A.K.; project administration, A.K., P.N.; funding acquisition, A.K. All authors have read and agreed to the published version of the manuscript.

Funding: The research has been supported by The Federal Government's research funding programme agreement No. 14.607.21.0205, project unique identifier RFMEFI60718X0205.

Conflicts of Interest: The authors declare no conflict of interest.

\section{Appendix A}

Table A1. Feedback of the negative electrical conductivity $\left(\lambda_{-}\right)$of the atmospheric surface layer during rain showers.

\begin{tabular}{|c|c|c|c|c|c|c|c|}
\hline No. & Date & $\begin{array}{c}\text { Start } \\
\text { Time, LT } \\
\text { (HH: MM) }\end{array}$ & $\begin{array}{c}\text { The } \lambda_{-} \\
\text {Significant } \\
\text { Increase Effect (\% } \\
\text { of Previous } \\
\text { Undisturbed } \lambda_{-} \\
\text {Values) }\end{array}$ & $\nabla \varphi, \times 10^{3} \mathrm{~V} / \mathrm{m}$ & $\mathrm{I}, \mathrm{mm} / \mathrm{h}$ & Synoptic Condition & $\begin{array}{c}\text { Cloudiness and } \\
\text { Weather } \\
\text { Phenomena }\end{array}$ \\
\hline 1 & 20 June 2018 & $22: 50$ & $+(666 \%)$ & $-12.1-+11.0$ & $5-48$ & Cold front (AF) & $\begin{array}{c}\mathrm{Cb}, \mathrm{Ac}, \mathrm{Ci} ; \\
\text { thunderstorm }\end{array}$ \\
\hline 2 & 20 July 2018 & $07: 30$ & $+(3900 \%)$ & $-8.2-0.0$ & $10-90$ & Cold front (AF) & Sc, $A c$ \\
\hline 3 & 28 July 2018 & $13: 40$ & $+(2500 \%)$ & $-1.4-2.7$ & $5-20$ & Occluded front (AF) & $C b, S c, A s$ \\
\hline 4 & 29 July 2018 & $16: 50$ & $+(300 \%)$ & $-12.6-+9.9$ & $3-12$ & Cold front (AF) & Sc, $A c, C i$ \\
\hline 5 & 11 August 2018 & $14: 40$ & $+(900 \%)$ & $-6.0-+2.7$ & $5-38$ & Cold front (AF) & $C b, A c$ \\
\hline 6 & 22 August 2018 & $17: 50$ & $+(500 \%)$ & $-2.2-+2.7$ & $3-17$ & Cold front (PF) & $\mathrm{Cb}, \mathrm{Sc}_{\mathrm{C}}$ \\
\hline 7 & 23 August 2018 & $20: 00$ & $+(4600 \%)$ & $-3.3-+3.3$ & $10-100$ & Occluded front (PF) & $C b, S c, A c$ \\
\hline 8 & 26 August 2018 & $13: 30$ & $+(250 \%)$ & $-12.6-+9.3$ & $3-23$ & Occluded front (PF) & $\begin{array}{c}C b ; \\
\text { thunderstorm }\end{array}$ \\
\hline 9 & 22 September 2018 & $16: 00$ & $+(766 \%)$ & $-7.7-+13.2$ & $5-50$ & Occluded front (PF) & $\begin{array}{c}C b, S c, A c ; \\
\text { thunderstorm }\end{array}$ \\
\hline 10 & 15 May 2019 & $16: 30$ & $-(90 \%)$ & $-13.7-+24.7$ & $3-24$ & Intra-mass (AM) & $\mathrm{Cb}, \mathrm{Ci}$ \\
\hline 11 & 19 May 2019 & $14: 15$ & $-(100 \%)$ & $-17.6-+22.0$ & $0.5-5$ & Intra-mass (PM) & $S_{c}, A c, C b$ \\
\hline 12 & 21 May 2019 & $18: 45$ & $-(71 \%)$ & $-20.3-+11.0$ & $2.5-17$ & Intra-mass (PM) & $C b, S c, A c$ \\
\hline 13 & 30 May 2019 & $17: 00$ & $+(675 \%)$ & $-11.0-+6.6$ & $5-75$ & Cold front (AF) & $\begin{array}{c}C b, S c, A c ; \\
\text { thunderstorm }\end{array}$ \\
\hline 14 & 31 May 2019 & $15: 00$ & $+(533 \%)$ & $-19.2-+19.2$ & $2.5-40$ & Cold front (AF) & $\begin{array}{l}\mathrm{Cb} ; \\
\text { thunderstorm }\end{array}$ \\
\hline 15 & 31 May 2019 & $18: 30$ & $+(833 \%)$ & $-5.5-+3.3$ & $3-22$ & $\begin{array}{l}\text { Secondary (surface) } \\
\text { cold front(s) at the rear } \\
\text { of the cyclone (AF) }\end{array}$ & $\begin{array}{c}C b ; \\
\text { thunderstorm }\end{array}$ \\
\hline
\end{tabular}


Table A1. Cont.

\begin{tabular}{|c|c|c|c|c|c|c|c|}
\hline 16 & 4 June 2019 & 01:20 & $+(314 \%)$ & $-8.2-+9.3$ & $6-50$ & $\begin{array}{l}\text { The low center (AF), } \\
\text { point of occlusion (the } \\
\text { warm and cold air } \\
\text { merger resulting in an } \\
\text { occluded front) }\end{array}$ & $C b, A c$ \\
\hline 17 & 4 June 2019 & 02:50 & $+(300 \%)$ & $-7.7-+10.4$ & $5-35$ & $\begin{array}{l}\text { The low center (AF), } \\
\text { point of occlusion (the } \\
\text { warm and cold air } \\
\text { merger resulting in an } \\
\text { occluded front) }\end{array}$ & $\mathrm{Cb}, \mathrm{Sc}$ \\
\hline 18 & 4 June 2019 & $11: 15$ & $+(1000 \%)$ & $-1.9-+1.6$ & $5-60$ & Occluded front (AF) & $\mathrm{Cb}$ \\
\hline 19 & 8 June 2019 & $15: 15$ & $+(300 \%)$ & $-5.5-+5.5$ & $4-32$ & $\begin{array}{l}\text { Secondary (surface) } \\
\text { cold front(s) at the rear } \\
\text { of the cyclone (AF), } \\
\text { where a squall line } \\
\text { forming along }\end{array}$ & $\begin{array}{c}\mathrm{Cb} \\
\text { thunderstorm }\end{array}$ \\
\hline 20 & 8 June 2019 & $17: 00$ & $+(625 \%)$ & $-8.2-+9.9$ & $5-45$ & $\begin{array}{l}\text { Secondary (surface) } \\
\text { cold front(s) at the rear } \\
\text { of the cyclone (AF), } \\
\text { where a squall line } \\
\text { forming along }\end{array}$ & $\mathrm{Cb}$ \\
\hline 21 & 13 June 2019 & $16: 45$ & $-(80 \%)$ & $-13.7-+11.0$ & $1-7$ & Intra-mass (PF) & $\begin{array}{c}C b, C s \\
\text { thunderstorm }\end{array}$ \\
\hline 22 & 13 June 2019 & $18: 50$ & $-(100 \%)$ & $-7.7-+6.6$ & $2-17$ & Occluded front $(\mathrm{PF})$ & $\begin{array}{c}\mathrm{Cb} \text {; } \\
\text { thunderstorm }\end{array}$ \\
\hline 23 & 17 June 2019 & $14: 15$ & $+(550 \%)$ & $-5.5-+0.55$ & $3-25$ & Intra-mass (AM) & Cu med, Cu cong \\
\hline 24 & 17 June 2019 & 18:00 & $+(450 \%)$ & $-10.4-+9.9$ & $5-45$ & Cold front (AF) & $\mathrm{Cb}, \mathrm{Ac}, \mathrm{Ci}$ \\
\hline 25 & 23 June 2019 & 01:55 & $-(125 \%)$ & $-10.4-+6.6$ & $4-25$ & Intra-mass (PM) & $C b, S c, A c$ \\
\hline 26 & 10 July 2019 & 00:00 & $+(633 \%)$ & $-13.7-+9.9$ & $2-14$ & Intra-mass (PM) & $\begin{array}{c}C b, S c ; \\
\text { thunderstorm }\end{array}$ \\
\hline 27 & 17 July 2019 & $11: 20$ & $-(100 \%)$ & $-10.4-+10.4$ & $3-11$ & Intra-mass (PM) & $\mathrm{Cb}, \mathrm{Ac}$ \\
\hline 28 & 3 August 2019 & 07:40 & $+(580 \%)$ & $-15.4-+8.2$ & $10-80$ & Cold front (PF) & $\begin{array}{l}\mathrm{Cb}, \mathrm{Ci} ; \\
\text { thunderstorm }\end{array}$ \\
\hline 29 & 10 August 2019 & 19:00 & $-(115 \%)$ & $-0.55-+1.6$ & $3-13$ & Intra-mass (AM) & $\mathrm{Sc}, \mathrm{Cb}$ \\
\hline 30 & 18 August 2019 & 20:05 & $-(100 \%)$ & $-8.8-0.0$ & $3-9$ & Intra-mass (PM) & $\mathrm{Cb}, \mathrm{Ac}, \mathrm{Ci}$ \\
\hline 31 & 20 August 2019 & $17: 45$ & $-(105 \%)$ & $-8.2-+7.1$ & $1-7$ & Intra-mass (AM) & $C b, S c, A c$ \\
\hline 32 & 27 August 2019 & $19: 40$ & $-(160 \%)$ & $-6.6-+11.0$ & $3-18$ & Intra-mass (PM) & $C b, A c$ \\
\hline 33 & 30 August 2019 & 21:00 & $-(100 \%)$ & $-6.6-+2.7$ & $2-15$ & Intra-mass (PM) & $\begin{array}{c}\mathrm{Ci}, \mathrm{Cb} ; \\
\text { thunderstorm }\end{array}$ \\
\hline 34 & 3 September 2019 & $15: 40$ & $+(1100 \%)$ & $-13.7-+13.7$ & $10-100$ & Occluded front (AF) & $\begin{array}{c}C b, A c ; \\
\text { thunderstorm }\end{array}$ \\
\hline 35 & 4 September 2019 & $15: 15$ & $-(110 \%)$ & $-8.2-+27.5$ & $1-8$ & Intra-mass (AM) & $\begin{array}{c}C i, S_{c}, C b \\
\text { thunderstorm }\end{array}$ \\
\hline 36 & 17 September 2019 & 21:00 & $-(97 \%)$ & $-12.1-10.4$ & $2-14$ & Intra-mass (PM) & $\begin{array}{c}\mathrm{Ci}, \mathrm{Ac}, \mathrm{Cb} ; \\
\text { thunderstorm }\end{array}$ \\
\hline 37 & 23 September 2019 & $13: 40$ & $+(200 \%)$ & $-2.7-+1.1$ & $5-18$ & Cold front (AF) & $\mathrm{Cb}, \mathrm{As}$ \\
\hline
\end{tabular}

\section{References}

1. Tverskoy, P.N. Atmospheric Electricity; Gidrometeoizdat: Leningrad, Russia, 1949; 700p. (In Russian)

2. Chalmers, J.A. Atmospheric Electricity, 2nd ed.; Pergamon Press: Oxford, UK, 1967; 526p.

3. Krasnogorskaia, N.V. Electricity of the Lower Layers of the Atmosphere and Methods of Its Measurement; Gidrometeoizdat: Leningrad, Russia, 1972; 323p. (In Russian)

4. Filippov, A.K. Thunderstorms in Eastern Siberia; Gidrometeoizdat: Leningrad, Russia, 1974; 75p. (In Russian)

5. Rakov, V.A.; Uman, M.A. Lightning: Physics and Effects; Cambridge University Press: New York, NY, USA, 2003; 687p. 
6. Bennett, A.J.; Harrison, R.G. Atmospheric electricity in different weather conditions. Weather 2007, 62, $277-283$. [CrossRef]

7. Popov, I.B. Statistical estimations of various of different meteorological phenomena influence on atmospheric electrical potential gradient. Proc. Voeikov Main Geophys. Obs. 2008, 558, 152-161. (In Russian)

8. Hoppel, W.A. Theory of the electrode effect. J. Atmos. Terr. Phys. 1967, 29, 708-721.

9. Latham, D.G.; Poor, H.W. A timedependent model of the electrode effect. J. Geophys. Res. 1972, 77, $2669-2676$. [CrossRef]

10. Hoppel, W.A.; Frick, G.M. Ion-aerosol attachment coefficients and the steady state charge distribution on aerosols in a bipolar ion environment. Aerosol Sci. Technol. 1986, 5, 1-21. [CrossRef]

11. Kupovykh, G.V.; Morozov, V.N.; Shvarts, Y.M. Theory of the Electrode Effect in the Atmosphere; TSURE Publishing: Taganrog, Russia, 1998; 124p. (In Russian)

12. Petrov, A.I.; Petrova, G.G.; Panchishkina, I.N. Profiles of polar conductivities and radon-222 concentration in the atmosphere by stable and labile stratification of surface layer. Atmos. Res. 2009, 91, 206-214. [CrossRef]

13. Morozov, V.N.; Kupovich, G.V. Theory of Electrical Phenomena in Atmosphere; LAP LAMBERT Academic Publishing: Saarbruken, Germany, 2012; 330p.

14. Anisimov, S.V.; Afinogenov, K.V.; Shikhova, N.M. Dynamics of undisturbed midlatitude atmospheric electricity: From observations to scaling. Radiophys. Quantum Electron. 2014, 56, 709-722. [CrossRef]

15. Anisimov, S.V.; Galichenko, S.V.; Shikhova, N.M.; Afinogenov, K.V. Electricity of the Convective Atmospheric Boundary Layer: Field Observations and Numerical Simulation. Izv. Atmos. Ocean. Phys. 2014, 50, 390-398. [CrossRef]

16. Adzhiev, A.K.; Kupovykh, G.V. Measurements of the Atmospheric Electric Field under High-Mountain Conditions in the Vicinity of Mt. Elbrus. Izv. Atmos. Ocean. Phys. 2015, 51, 633-638. [CrossRef]

17. Yaniv, R.; Yair, Y.; Price, C.; Katz, S. Local and global impacts on the fair-weather electric field in Israel. Atmos. Res. 2016, 172, 119-125. [CrossRef]

18. Anisimov, S.V.; Galichenko, S.V.; Mareev, E.A. Electrodynamic properties and height of atmospheric convective boundary layer. Atmos. Res. 2017, 194, 119-129. [CrossRef]

19. Kamra, A.K. Effect of electric field on charge separation by the falling precipitation mechanism in thunderclouds. J. Atmos. Sci. 1970, 27, 1182-1185. [CrossRef]

20. Illingworth, A.J.; Latham, J. Calculations of electric field growth, field structure and charge distributions in thunderstorms. Q. J. R. Meteorol. Soc. 1977, 103, 281-295. [CrossRef]

21. Chauzy, S.; Raizonville, P. Space charge layers created by coronae at ground level below thunderclouds: Measurements and modeling. J. Geophys. Res. 1982, 87, 3143-3148. [CrossRef]

22. Chauzy, S.; Médale, J.; Prieur, S.; Soula, S. Multilevel measurement of the electric field underneath a thundercloud: 1. A new system and the associated data processing. J. Geophys. Res. 1991, 96, 22319-22326. [CrossRef]

23. Petersen, W.A.; Rutledge, S.A. On the relationship between cloudto-ground lightning and convective rainfall. J. Geophys. Res. Atmos. 1998, 103, 14025-14040. [CrossRef]

24. Stolzenburg, M.; Marshall, T.C. Charged precipitation and electric field in two thunderstorms. J. Geophys. Res. Atmos. 1998, 103, 19777-19790. [CrossRef]

25. Lang, T.J.; Rutledge, S.A. Relationships between convective storm kinematics, precipitation, and lightning. Mon. Weather Rev. 2002, 130, 2492-2506. [CrossRef]

26. Soula, S.; Chauzy, S.; Chong, M.; Coquillat, S.; Georgis, J.-F.; Seity, Y.; Tabary, P. Surface precipitation electric current produced by convective rains during the Mesoscale Alpine Program. J. Geophys. Res. 2003, 108, 4395. [CrossRef]

27. Bennett, A.J.; Harrison, R.G. Variability in surface atmospheric electric field measurements. J. Phys. Conf. Ser. 2008, 142, 012046. [CrossRef]

28. Liou, Y.-A.; Kar, S.K. Study of cloud-to-ground lightning and precipitation and their seasonal and geographical characteristics over Taiwan. Atmos. Res. 2010, 95, 115-122. [CrossRef]

29. Klimenko, V.V.; Mareev, E.A.; Shatalina, M.V.; Shlyugaev, Y.V.; Sokolov, V.V.; Bulatov, A.A.; Denisov, V.P. On statistical characteristics of electric fields of the thunderstorm clouds in the atmosphere. Radiophys. Quantum Electron. 2014, 56, 778-787. [CrossRef]

30. Nagorsky, P.M.; Smirnov, S.V.; Pustovalov, K.N.; Morozov, V.N. Electrode layer in the electric field of deep convective cloudiness. Radiophys. Quantum Electron. 2014, 56, 769-777. [CrossRef] 
31. Pustovalov, K.N.; Nagorskiy, P.M. Response in the surface atmospheric electric field to the passage of isolated air mass cumulonimbus clouds. J. Atmos. Solar Terr. Phys. 2018, 172, 33-39. [CrossRef]

32. Pustovalov, K.N.; Nagorskiy, P.M. Comparative Analysis of Electric State of Surface Air Layer during Passage of Cumulonimbus Clouds in Warm and Cold Seasons. Atmos. Ocean. Opt. 2018, 31, 685-689. [CrossRef]

33. Bernard, M.; Underwood, S.J.; Berti, M.; Simoni, A.; Gregoretti, C. Observations of the atmospheric electric field preceding intense rainfall events in the Dolomite Alps near Cortina d'Ampezzo, Italy. Meteorol. Atmos. Phys. 2019, 132, 99-111. [CrossRef]

34. Hirsikko, T.; Laakso, L.; Nieminen, S.; Gagné, S.; Lehtipalo, K. Atmospheric Ions and Nucleation: A Review of Observations. Atmos. Chem. Phys. 2011, 11, 767-798. [CrossRef]

35. Dhanorkar, S.; Kamra, A.K. Diurnal and seasonal variations of the small-, intermediate-, and large-ion concentrations and their contributions to polar conductivity. J. Geophys. Res. 1993, 98, 14895-14908. [CrossRef]

36. Horrak, U.; Salm, J.; Tammet, H. Diurnal variation in the concentration of air ions of different mobility classes in a rural area. J. Geophys. Res. 2003, 108, 4653. [CrossRef]

37. Kamra, A.K.; Gautam, A.S.; Siingh, D. Charged Nanoparticles Produced by Splashing of Raindrops. J. Geophys. Res. Atmos. 2015, 120, 6669-6681. [CrossRef]

38. Tammet, H.; Hõrrak, U.; Kulmala, M. Negatively Charged Nanoparticles Produced by Splashing of Water. Atmos. Chem. Phys. 2009, 9, 357-367. [CrossRef]

39. Laakso, L.; Hirsikko, A.; Grönholm, T.; Kulmala, M.; Luts, A.; Parts, T.-E. Waterfalls as sources of small charged aerosol particles. Atmos. Chem. Phys. 2007, 7, 2271-2275. [CrossRef]

40. Levin, Z. Charge Separation by Splashing of Naturally Falling Raindrops. J. Atmos. Sci. 1971, $28,543-548$. [CrossRef]

41. Geophysical Observatory, IMCES SB RAS (GO IMCES). Available online: http://www.imces.ru/index.php? rm=news\&action=view\&id=899 (accessed on 1 September 2020).

42. Azbukin, A.A.; Bogushevich, A.Y.; Korolkov, V.A.; Tikhomirov, A.A.; Shelevoi, V.D. A field version of the AMK-03 automated ultrasonic meteorological complex. Russ. Meteorol. Hydrol. 2009, 34, 133-136. [CrossRef]

43. Kalchikhin, V.V.; Kobzev, A.A.; Korolkov, V.A.; Tikhomirov, A.A. Detection of microstructure characteristics of liquid atmospheric precipitation with the optical rain gage. Atmos. Ocean. Opt. 2016, 29, 304-307. [CrossRef]

44. Kalchikhin, V.V.; Kobzev, A.A.; Korolkov, V.A.; Tikhomirov, A.A. Results of optical precipitation gage field tests. Atmos. Ocean. Opt. 2018, 31, 545-547. [CrossRef]

45. Hydrometeorological Center of Russia. Available online: https://meteoinfo.ru/mapsynop (accessed on 1 September 2020).

46. EOSDIS Worldview. Available online: https://worldview.earthdata.nasa.gov (accessed on 1 September 2020).

47. Marshall, T.C.; Stolzenburg, M.; Krehbiel, P.R.; Lund, N.R.; Maggio, C.R. Electrical evolution during the decay stage of New Mexico thunderstorms. J. Geophys. Res. 2009, 114, D02209. [CrossRef]

Publisher's Note: MDPI stays neutral with regard to jurisdictional claims in published maps and institutional affiliations.

(C) 2020 by the authors. Licensee MDPI, Basel, Switzerland. This article is an open access article distributed under the terms and conditions of the Creative Commons Attribution (CC BY) license (http://creativecommons.org/licenses/by/4.0/). 